\title{
The Effect of Health Education on the Implementation of Early Mobilization in Post op Abdomen Patients in the Surgical Ward of Pariaman's RSUD in 2018
}

\author{
Linda Marni ${ }^{*}$, Aulia Asman ${ }^{2}$, and Erpita Yanti ${ }^{3}$ \\ ${ }^{1,2,3}$ Lecture at Associate's Degree of Nursing, Faculty of Sports Sciences, Universitas Negeri Padang, Padang, \\ Indonesia \\ *Corresponding author. Email: apriagusfik@gmail.com
}

\begin{abstract}
Mobilization will also prevent muscle and joint stiffness, ensure smooth circulation of blood, improve the regulation of the body's metabolism, restore physiological work of vital organs which in turn will accelerate the healing of patients and reduce the cost of patient care. The type of research that was used quasi experimental with the design of one group pretest-posttest design. This research had been done out in RSUD Pariaman's surgical ward, it had been being starting since on 5 to 24 July 2018. The populations were all patients with post op abdomen treated in surgical wards totaling 87 people. Samples were taken by accidental sampling with a sample of 15 people. Data collection was done by observing and filled directly by researchers and given health education about early mobilization with the consent of respondents. Data processing stage through editing, coding, entry, cleaning and tabulating using univariate and bivariate analysis. The results of univariate research showed that the average implementation of early mobilization before being given health education was 0.80 and the average after being given health education was 3.53. And the results of bivariate research using Wilcoxon test have an influence between health education on the implementation of early mobilization of patients post op abdomen with $\mathrm{p}$ value 0.001 .
\end{abstract}

Keywords: Health Education, Early Mobilization, Laparatomy

\section{INTRODUCTION}

Health development goals towards Healthy Indonesia 2018 is to increase awareness, willingness and ability of healthy life for everyone to realize the degree of public health optimally through the creation of a community of the nation and state of Indonesia is characterized by its inhabitants who live with behavior and in a healthy environment to reach quality health services fair and equitable manner and has a degree of optimal health throughout the Republic of Indonesia.

National Tabulation Data Indonesian Ministry of Health in 2016 following surgery ranks 11th out of 50 first pattern of disease in hospitals in Indonesia with a percentage of $12.8 \%$, an estimated $32 \%$ of which is an act of laparotomy [1].

Based on the data obtained from medical records in hospitals Pariaman January to May 2018 in which the act of abdominal surgery as many as 87 people (Medical Recor Pariaman Public Hospital).

While the results of the initial survey that researchers do in maintainability Surgical Hospital Pariaman on March 29 s / d 21 April 2018 on 10 patients after abdominal surgery in which the patient 5 of the 10 were able to do early mobilization postoperatively as 6 hours post-surgery patients were able to tilt left and right, moving the legs by bending and straightening so its good intestinal peristalsis and 12 hours post-surgery patient is able to sit up in bed and dangling his legs. 5 other people would not perform postoperative mobilization because no knowledge of how the benefits of early mobilization after the operation. While 12 hours after surgery the patient is not able to sit on the bed even walk to the bathroom.

Based on the phenomenon of researchers conducted a study "Effect of health education on the implementation of early mobilization in post-op patients abdomen in Pariaman Hospital Surgical Ward".

"Is there any effect on the health education the implementation of early mobilization in post-op patients abdomen in Pariaman Public Hospital? "General Objective To know the influence of health education on the implementation of early mobilization post-op patients abdomen in Pariaman Hospital Surgical Ward. Knowledgeable average implementation of early mobilization in patients post-op abdomen before being given a health education treatment. Knowledgeable 
average execution early mobilization of patients post-op abdomen after treatment given health education Knowledgeable health pedidikan their influence on the implementation of early mobilization in post-op patients abdomen in Pariaman Hospital surgical ward.

\section{METHODS}

The study design was quantitative, while the type of study is a quasi-experimental research design with One group pretest-posttest design. (Notoatmodjo, 2012),

RDefinition of these studies are as follows: Pretest Treatment Posttest

$01 \times 02$

This research has been conducted in Pariaman Hospital Surgical Ward. On 5 s / d July 26th 2018. The population in this study were all patients who will perform abdominal surgery during February s / d April 2018, as many as 87 people. Sampling was done by purposive sampling (Notoatmodjo, 2010). In this study, researchers took a sample of 15 patients post abdominal surgery.There are several techniques of data collection (Notoadmodjo, 2010): Primary data, and Secondary Data. After abdominal surgery, researchers then observed 6 hours post-surgery respondents then rated whether to perform or not early postoperative mobilization and do penceklistan on the blank observation. A blank is then given informed consent to the respondents observed for a given health education on the implementation of early postoperative mobilization and observations execution of early mobilization after treated 60 minutes after respondents were given health education.

Univariate analysis was done by finding the frequency distribution of each variable researchers to determine the proportion or description of the independent variables, health education and the dependent variable is the implementation of early mobilization.

Bivariate analysis was conducted to see the relationship between the independent variables and the dependent variable is the effect of health education on the implementation of early mobilization in patients after abdominal surgery in Pariaman Hospital surgical ward. Once completed and input on the research results and data normality test showed abnormal results (pretest and posttest $=0.004=0.000$ ) which shows the results of $<0.05$, Therefore, the researchers analyzed the bivariate using Wilcoxon test and the results obtained $\mathrm{p}$

value $=0.001$. The results of these studies show the influence of health education with the implementation of early moblisasi because it shows the $p$ value $\leq 0.05$, but if the $p$ value $>0.05$, there is no influence of the independent variables with the dependent variable.

\section{RESULT AND DISCUSSION}

\section{A. Result}

Research has been conducted on 5 s / d July 25th 2018 on the effect of health education on the implementation of early mobilization in Pariaman Hospital Surgical Ward, the research results obtained are:

Univariate analysis was conducted to see the average and standard deviation of implementation of mobilization before being given health education.

a. Average Mobilization Early Implementation Before Provided Health Education

Table 1. Average Mobilization Early Implementation Before Health Education Given In Ward Pariaman Hospital Surgery 2018

\begin{tabular}{|r|r|r|r|r|}
\hline Variables & mean & SD & Min-Max & n \\
\hline $\begin{array}{c}\text { plementation of } \\
\text { rly mobilization } \\
\text { before penkes }\end{array}$ & 0.80 & 0.676 & $0-2$ & 15 \\
\hline
\end{tabular}

In Table 4.1 shows that the average implementation of early mobilization before being given health education is 0.80 with a standard deviation is 0.676 . The lowest value is 0 and the second highest in the Surgical Hospital Pariaman 2018

b. The mean Implementation of Early Mobilization After Provided Health Education

Table 2. Average Mobilization Early After Execution Health Education given in Ward Pariaman Hospital Surgery 2018

\begin{tabular}{|c|r|r|r|}
\hline Variables & mean & SD & Min-Max \\
\hline $\begin{array}{c}\text { implementation of } \\
\text { early mobilization after } \\
\text { being given penkes }\end{array}$ & 3.53 & 0.516 & $3-4$ \\
\hline
\end{tabular}

In Table 4.2 shows that the average implementation of early mobilization after being given health education is 3.53 with a standard deviation is 0.516 . The lowest value is 3 and the fourth highest in the Surgical Hospital Pariaman 2018.

Bivaria analysis conducted to see the effect of health education on the implementation of early mobilization. 
Table 3. Effect of Education Implementation Case Mobilization Against Early in the Surgical Hospital Pariaman 2018

\begin{tabular}{|c|c|c|c|c|c|}
\hline variables & N & $\begin{array}{c}\text { Med } \\
\text { ian }\end{array}$ & $\begin{array}{c}\text { Min- } \\
\text { Max }\end{array}$ & Z & P Value \\
\cline { 1 - 4 } $\begin{array}{c}\text { Early } \\
\text { mobilizati } \\
\text { on Pre }\end{array}$ & \multirow{2}{*}{15} & $1: 00$ & $0-2$ & & \\
\cline { 1 - 1 } $\begin{array}{c}\text { Early } \\
\text { mobilizati } \\
\text { on Post }\end{array}$ & & $4: 00$ & $3-4$ & -3.464 & 0,001 \\
\cline { 3 - 5 } & & & & \\
\hline
\end{tabular}

Based on the results obtained Table 4.3 Wilcoxon test after which the normality test of data on the implementation of early mobilization that the distribution is not normal is signed 0,004 to 0,000 for the pre and post that is both data $<0.05$, with correlation between the implementation of early mobilization before and after can be ensured by using the Wilcoxon signed ranks test. Following the Wilcoxon signed ranks test showed that where the $\mathrm{p}$ value $0.001<0.05$ was known of the effect of health education on the implementation of early mobilization in post-op patients abdomen in Pariaman Hospital surgical ward 2018.

\section{B. Discussion}

Based on the research that has been done, it was found that the average implementation of early mobilization before being given health education is 0.80 with a standard deviation is 0.676 . The lowest value is 0 and the second highest in the Surgical Hospital Pariaman 2018.

The results are consistent with research that has been done by Agritubella (2014) concerning the effect of the implementation of health promotion in the early mobilization of postpartum mothers in Inpatient Obstetrics Pekanbaru RSPB in 2015, found an average implementation of early mobilization before being given a health promotion as much as 0.47 .

Along with theoretical understanding of the mobilization which requires more than an understanding of the physiological movement, as well as the regulation of the movement by muskuloskletal system and the nervous system. People around the patient (family or nurses) need to know about how to apply the principles of clinical ketatanan to determine the safest way of moving the patient and understand the effects of immobilization on the physiological, psychosocial and development of client care [2]

Based on the analysis the researchers assume that the results of the study the researchers did that implementation mobilisi influenced by the age of the respondents who do not want to do a mobilization that was dominant in moving leg and contracting the muscles while the movement if the patient completed the operation and immediately move the patient will more quickly facilitate circulation to prevent venous stasis. Indeed, early mobilization postoperatively need support and information from the closest and nurses who diruangan services so that patients can be motivated to do the mechanics of the body. Mobilization can lead to improved circulation, creating a deep breath and stimulate gastrointestinal function returns to normal, push to move the lower leg feet as soon as possible usually within 6 hours after the patient is conscious of the effect of the full anesthesia. But due to lack of support and information resulting lack motivation against the respondent. After 6 hours postoperatively respondents had diobservaasi implementation of early mobilization. Having observed the respondent is given health education to seek approval (informed consent) and respondents described on the definition, objectives and ways of doing early mobilization by using a flip chart. After respondents were given health education leaflets as a handle for the study, and 60 minutes after being given health education respondents observed again with reference to the observation sheet.

Based on the results that the average implementation of early mobilization before being given health education is 3.53 with a standard deviation is 0.516 . The lowest value is 3 and the fourth highest in the Surgical Hospital Pariaman Year 2018 of 4 points observed by researchers. This shows her no significant influence of health education with the implementation of the mobilization.

The results are consistent with research that has been done by Oktasari (2013) on the effect of health education on the implementation of active joint motion postoperatively in patients with extremity fractures in the room trauma center DR M.Djamil Padang, found an average execution after being given the range of motion sendii health education as much as 28.40 and has increased than before given health education.

Based on the theory that a good knowledge of the use of body mechanics will encourage someone to use it properly, thus reducing the energy released. Conversely, inadequate knowledge in the use of body mechanics will run a person at risk for neurological disorders and musculoskeletal system coordination.

Based on the results obtained can researchers assume that after respondents were given treatment that health education about early mobilization postoperatively that give a positive effect to the respondent with an increase of the average before being treated and after being treated. Respondents who have been taught about the early postoperative mobilization would provide an alternative experience the impact will increase. Information on what to expect, including a sensation during and after treatment may encourage 
patients to participate actively in the development and application of experience. In this study can be seen from the observation sheet item post-test that $100 \%$ of respondents do move the limbs that can ditekukan and straightened as well as more than half of the respondents were able to tilt left and right. The movement has the benefit of a good after the surgery because it can stimulate the bowel (intestinal peristalsis) so that the patient will be faster fart / flatus, blood flow and increasing the strength of muscle tone to the respondents were able to do his own aktifita.

Based on table 4.3 be obtained Wilcoxon test results obtained value $P$ value of 0.001 , meaning at $p$ value $<0.05$ seen no effect of health education on the implementation of early mobilization in the Surgical Hospital Pariaman 2018. In the Wilcoxon test is no decrease or reduction in the value of values pretest to posttest value. In the 15 respondents have increased prestest to posttest results and there is no value in the same test results.

The results are consistent with research that has been done by Radnyani (2014) concerning the Effect of Preoperative Teaching Early Mobilization Against Execution Post Surgery appendectomy at Sanglah Hospital shows that there is a significant correlation between the preoperative administration of teaching on the implementation of the results of early mobilasisi $\mathrm{p}$ value $=0.008$,

In line with the theory According Notoadmodjo (2012) Health promotion aims to upload awareness, provide or increase public knowledge about the maintenance and improvement of health for themselves, their families and society. and according toDombovy ML cited by Rismalia (2010), suggests that some principles in mobilizing preventing and reducing secondary complications to a minimum, the loss of motor function, providing environmental stimuli, encouraging socializing, giving the opportunity to be able to function and perform daily activities as well as lets do the job as before.

Can researchers assume that there are several factors that influence a person's behavior, one of which is the level of knowledge. The level of knowledge about early mobilization can be obtained by carrying out health education about early mobilization in the hope of knowledge mobilization could affect the implementation of early postoperative mobilization, knowledge will impact positive behaviors to cure himself. Some of the respondents and the family said on researchers that they felt calm after the mobilization and feel relaxed and feel tenag so it gives tranquility to the patient.

\section{CONCLUSION}

Effect of health education on implementing early mobilization on postop patients abdomen in Pariaman Hospital Surgical Ward in 2018, it can be concluded as follows. The average implementation of early mobilization before being given health education is 0.80 with a standard deviation is 0.676 . The lowest value is 0 and the second highest in the Surgical Hospital Pariaman 2018. The average implementation of early mobilization after being given health education is 3.53 with a standard deviation is 0.516 . The lowest value is 3 and the fourth highest in the Surgical Hospital Pariaman 2018. The influence of health education on the implementation of early mobilization on postop patients abdomen in Pariaman Hospital surgical ward with a significance level $\mathrm{p}$ value $=0.001$.

\section{REFERENCES}

[1] Ministry of Health, Ri, D., \& MoH RI. (2017). Kepmenkes Affairs, No. 854 / Menkes / SK / IX / 2009. Data and Information Center of the Ministry of Health

[2] A Potter \& Perry, AG 2007. Textbook Fundamentals of Nursing

[3] Abraham H. Maslow, 2010, Motivation and Personality.Rajawali, Jakarta.

[4] Arief, Mansjoer. 2001. Capita Selecta Medicine. Jakrta: Media AESC treatment: Concept, .it, And Practice, Edisi4, VOLUME2. Jakarta: EGC.ulapius.

[5] Arikunto, Suharsimi, 2013 Procedure Research: A Practical Approach, Fifteenth mold. Jakarta: Rineka copyright

[6] Azwar. Saifuddin. 2013. Research Methods. Yogyakarta: Student Library.

[7] Cetrione JH (2009). Fundamentals of Nursing: Human Health and Function. Philadelphia: Lippincott Williams \& Wilkins.Craven \& Hirnle. 2000. Fundamentals of Nursing. Philadelphia: Lippincott

[8] Dorland, WA Newman. 2011. Dorland Medical Dictionary. Jakarta: Book Medical Publishers. EGC

[9] Fertman, CI and DD Allenswort. 2010. Health Promotion Programs from Theory to Practice. Jossey -Bass. San Francisco.

[10] ML Gallagher. 2008. The Nutrients and Their Metabolism. In: Mahanan LK, Escott-Stump S. Krause's Food, Nutrition, and Diet Therapy.Philadelphia: Saun

[11] Hidayani, E. 2018.Educational Effect of Early Mobilization Mobilization Against Conduct PostSurgical Patients In Hernioraphy at Kenanga 
Lounge dr.H.Soewondo Kendal Hospital. Medical Journal 2018

[12] Hinchliff, Sue. 1999. Dictionary of Nursing. Jakarta: EGC

[13] Kozier. 2010. Book Ajr Fundamentals of Nursing: Concepts, Process and Practice. Jakarta. EGCMajid, Abdul, et al. 2011. Perioperative Nursing. Issue 1. Yogyakarta: Goysen Publishing

[14] Potter, PA, \& Perry, AG (2005). Textbook fundamentals of nursing: concepts, processes, and practices. Jakarta: EGC

[15] Ramali, Ahmad, 2000. Medical Dictionary, Jakarta: PT.Djambata.
[16] Sarwono, SW Adolescent Psychology Revised Edition. Jakarta: King Grafindo Persada. 2012

[17] Sjamsuhidajat, R \& Wim, de Jong (ed). 2004. Textbook of Surgery. Jakrta: EGC

[18] Smeltzer, Suzanne C., et al, 2001.Buku Festive Medical Surgical Nursing. (Issue 8). Jakarta, EGC

[19] Soelaiman. (2000). Early mobilization postoperatively. Taken on April 29 2018jam19: 00pmdarihttp://medica.store.com/mobilisasi/pasca/ operasi.html

[20] Sugiyono, 2014. Quantitative Research Methods, Qualitative dab RAD. Bandung: Alfabeta. 